\title{
Protective Role of N-Acetylcysteine on the Cytotoxic Effect of Paclitaxel in MCF7 Breast Cancer Cell Line
}

\author{
Aysegul Bildik (Corresponding Author) \\ Adnan Menderes University, Veterinary Medicine Faculty \\ Biochemistry Department, Aydin, Turkey \\ E mail: abildik@adu.edu.tr \\ Gamze Sevri Ekren Asici \\ Adnan Menderes University, Veterinary Medicine Faculty \\ Biochemistry Department, Aydin, Turkey \\ Yasemin Oruc \\ Adnan Menderes University, Graduate School of Health Sciences \\ Aydin, Turkey
}

The research is financed by Adnan Menderes University Scientific Research Projects Coordination Unit. No. VTF-17030

\begin{abstract}
$\mathrm{N}$-Acetylcysteine (NAC) is a low molecular weight and thiol-containing antioxidant. The free radical scavenging property is linked to the nucleophilicity and redox interactions of the thiol group. The aim of this study was to investigate the cytotoxic effect of paclitaxel used in chemotherapeutic treatment of breast cancer and N-Acetylcysteine, an antioxidant molecule, on MCF7 cells.

In the MCF7 breast cancer cell line, the cytotoxic effect of paclitaxel is $7.5 \mu \mathrm{M}$ and $10 \mu \mathrm{M}$ and Nacetylcysteine's $10 \mathrm{mM}, 25 \mathrm{mM}, 50 \mathrm{mM}, 75 \mathrm{mM}$ dose combinations on the cells were determined by WST1 test at 24, 48 and 72 hours incubation times.

$\mathrm{N}$-Acetylcysteine showed proliferative effect on breast cancer cells. This effect persisted when combined with paclitaxel and weakened the cytotoxic effect of paclitaxel. However, the proliferative effect of NAC decreased with increasing incubation time. Colony forming ability of applied combinations at MCF 7 cells is also supports the results of cytotoxicity. In vivo and in vitro longer-term studies that will be used concurrently with conventional cancer treatment and NAC will contribute to clarify the issue.
\end{abstract}

Key words: N-Acetylcysteine, paclitaxel, MCF7

Special Issue of Health Sciences

DOI: $10.7176 /$ JSTR/6-03-23

\section{MCF7 Meme Kanser Hücre Hattında Paklitakselin Sitotoksik Etkisi Üzerine N-Asetilsisteinin Koruyucu Rolü}

\section{Özet}

N-Asetilsistein (NAC), düşük molekül ağırlıklı tiyol içeren bir antioksidandır. Serbest radikal temizleme özelliği, tiyol grubunun nükleofilikliği ve redoks etkileşimlerine bağlanmıştır. Bu çalışmada meme kanserinin kemoterapotik tedavisinde kullanılan paklitaksel ile birlikte antioktioksidan molekül olan NAsetilsisteinin MCF7 hücreleri üzerine stotoksik etkisi araştırıldı. 
MCF7 meme kanser hücre hattında, paklitakselin, 7,5 $\mu \mathrm{M}$ ve $10 \mu \mathrm{M}$; N-Asetilsisteinin ise $10 \mathrm{mM}$, $25 \mathrm{mM}, 50 \mathrm{mM}, 75 \mathrm{mM}$ doz kombinasyonları 24, 48 ve 72 saat inkubasyon sürelerinde, hücreler üzerine sitotoksik etkisi WST1 testi ile belirlendi.

$\mathrm{N}$-Asetilsistein, meme kanser hücreleri üzerinde proliferatif etki gösterdi. Bu etkinin paklitaksel ile birlikte kombine uygulandığında da devam ettiği, paklitakselin sitotoksik etkisini zayıflattığı görüldü. Ancak NAC'ın proliferatif etkisinin inkubasyon süresi arttıkça azaldığı saptandı. Kombinasyonların uygulandığ1 MCF7 hücrelerinin koloni oluşturabilme yetenekleri de sitotoksite sonuçlarını desteklemektedir. Konvensiyonel kanser tedavisi ile NAC'ın eşzamanlı kullanılacağı daha uzun süreli invivo ve invitro araştırmalar konunun aydınlatılmasına katkı sağlayacaktır.

Anahtar kelimeler: N-Asetilsistein, paklitaksel, MCF7

\section{Giriş}

Vücudun doku ve organlarını oluşturan hücrelerin kontrolsüz ve anormal bir şekilde çoğalması kanser olarak tanımlanır. Hücreye dışardan etki eden radyasyon, uv 1şık, virüs, sigara dumanı gibi bazı genotoksik faktörler ya da kalıtsal mutasyon, hücresel onarım mekanizmalarının bozulması gibi iç faktörlerin kanser oluşumunda etkin rol oynadığı bilinmektedir. DNA replikasyonu esnasında meydana gelen mutasyonlar kanser hücrelerinin oluşumu ile sonuçlanır. Vücudun tüm doku ve organlarında kanser oluşabilir. Daha genel bir ifade ile kanser, genetik ve epigenetik sonuçlara sebep olan büyümesi kontrol edilemeyen, çeşitli organ ve dokulara yayılım gösterebilen bir durumdur (Cho ve ark.,2014; Valko ve ark.,2006). Modern toplum, teknolojik aletlerin kullanımındaki artış, besinlerdeki katkılar, ultraviyole 1şık gibi çeşitli nedenlerden kanser vakaları hızla artmaktadır. Halen en etkili tedavi kemoterapidir. Kemoterapi, meme kanseri tedavisinde uygulanan en yaygın ve etkili yöntemdir. Ancak, kemoterapi süresince, hastaların tedaviye cevap vermemesi veya tedavi sonrası kanserin tekrarlaması sıklıkla görülen bir durumdur (Kars Demirel ve ark., 2009; Papet ve ark., 2011).

Paklitaksel (Taksol) en aktif kanser kemoterapötik ajanlarından biridir. Over, meme ve küçük hücreli dışı akciğer tümörlerinin yanı sıra baş boyun kanserleri gibi çeşitli insan tümörlerine karşı etkilidir. Paklitaksel, 1967 yılında Monroe E. Wall ve Mansukh C. Wani tarafindan Pasifik porsuk ağacı (Taxus brevifolia) kabuğundan izole edilmiş yarı sentetik ve taksan grubundan kemoterapotik bir ilaçtır. Paklitaksel mitoz bölünme sırasında mikrotübüllerin $\beta$-Tübülin alt grubuna bağlanarak, mikrotübüllerin tübülinlere dönüşmesini ve mitoz bölünme sırasında oluşan iğ ipliklerinin yıkımını engeller ve hücre bölünmesini durdurur. Hücre siklusunu G2/M fazında durdurup apopitozisi tetikler ve sitoktoksisiteye neden olur. Paklitakselin indüklediği sitotoksisite ve apopitozis arasındaki pozitif korelasyon in-vivo olarak da gösterilmiştir (Fukui ve ark.,2010; Özfiliz, 2013).

Biyolojik sistemlerdeki en önemli serbest radikaller, oksijenden türeyen serbest oksijen radikalleridir (ROS). ROS, hem endojen hem de eksojen maddelerden üretilebilir. ROS, biyolojik sistemler için faydalı yada zararlı rol oynayabilir (Valko ve ark, 2007). ROS'un faydalı etkileri, örneğin enfeksiyöz ajanlara karşı savunma ve bir dizi hücresel sinyalleşme sisteminin işlevinde olduğu gibi, zararlı etkilere karşı hücrenin verdiği fizyolojik tepkileri içerir. Düşük konsantrasyonlarda ROS'un bir başka faydası, mitojenik yanıtın indüklenmesidir. ROS'un çok sayıda genin ve sinyal iletim yollarının ekspresyonuna müdahale ettiği açıkça kanıtlanmıştır. Buna karşılık, oksidatif stres olarak adlandırılan yüksek konsantrasyonlarda ROS, lipitler membranlar, proteinler ve nükleik asitler dahil hücre yapılarına zarar verir (Poli ve ark., 2004). ROS'un zararlı etkileri antioksidan enzimler ve enzimatik olmayan antioksidanların etkisiyle dengede tutulur. Hücrenin antioksidan savunma sistemine rağmen yaşam döngüsü boyunca biriken oksidatif hasar, DNA'ya, proteinlere ve lipitlere hasar verebilir; kanser, arteriyoskleroz, artrit, nörodejeneratif hastalıklar ve yaşa bağlı diğer durumlar gibi hastalıkların gelişiminde kilit rol oynar (Cadenas ve Davies, 2000).

Birçok tümör destekleyicileri, SOD, katalaz, glutatyon vb. gibi hücresel antioksidan savunma sistemleri üzerinde güçlü bir inhibe edici etkiye sahiptir. Yüksek seviyede oksidatif stres hücre için sitotoksiktir ve apoptoz, hatta nekrozu indükleyerek proliferasyonu durdururken, düşük seviyedeki oksidatif stres aslında çoğalma aşamasında hücre bölünmesini uyarabilir ve böylece tümör büyümesinin ilerlemesini indükleyebilir (Valko ve ark.2006). Biyolojik sistemler, antioksidan savunma mekanizmaları ile serbest radikallerin zararlı etkilerini ortadan kaldıran savunma sistemleri geliştirmişlerdir. Antioksidanlar; lipit peroksidasyonunu engellerler ve okside olan substratlara göre daha az konsantrasyonlarda bile substratın oksidasyonunu geciktirirler ve inaktif duruma getirirler $\mathrm{Bu}$ gibi antioksidanlar, serbest radikallerin (prooksidantlar) doğrudan uzaklaştırılmasını temsil ettiği için son derece önemlidir, bu nedenle biyolojik alanlar için maksimum koruma sağlar. En etkili enzimatik antioksidanlar süperoksit dismutaz, katalaz ve glutatyon peroksidazdır (Mates ve ark. 1999). Enzimatik olmayan antioksidanlar C vitamini, E vitamini, 
karotenoidle; glutation, tioredoksin ve lipoik asit gibi tiyol antioksidanları, doğal flavonoidler, pineal bezin hormonal bir ürünü melatonin ve diğer bileşikleri içerir (McCall ve Frei, 1999). Tümör hücrelerinde artmış ROS düzeyleri ile enzimatik ve enzimatik olmayan antioksidanların dengesiz aktiviteleri arasında bir bağlantı vardır.

Glutatyon (GSH),çok işlevli bir hücre içi enzimatik olmayan antioksidandır. Hücrenin ana tiyol-disülfür redoks tamponu olduğu düşünülmektedir. Glutatyon sitosol (1-11 mM), çekirdekler (3-15 mM) ve mitokondri (5-11 mM)de oldukça bol bulunur ve bu hücre kombonentlerinin major soluble antioksidanıdır. Çekirdekteki GSH, DNA onarımı ve ekspresyonu için gerekli olan kritik protein sülfidrillerin redoks durumunu korur. GSH, detoksifikasyon; hücresel redoks durumun modülasyonu ve redoks duyarlı hücre sinyallizasyon yolakları; pro- ve anti-apoptotik sinyallerle etkileşimleri içeren çok faktörlü mekanizmalarla hücreleri apoptotise karşı korur (Masella ve ark.,2005). GSH düzeyi apoptoza karş1 korunmada önemli bir faktör olduğundan, antikanser ilaca bağlı apoptozun etkinliği, GSH'nın tükenmesini gerektirir, böylece tümör tedavisini kolaylaştırır (Valko ve ark.,2006).

Aminotiyol ve hücre içi sistein ve GSH'nin sentetik bir öncüsü olan N-asetilsistein (NAC), uzun yıllar mukolitik bir madde olarak ve parasetamol zehirlenmesinde ana yan etkileri olmadan tercih edilen ilaç olarak kullanılmıştır (Duran ve ark., 2011). Moleküler yapısı nedeniyle N-Asetilsisteinin; hücre içine kolayca girebildiği ve glutatyon (GSH) oluşumunda öncül rol oynayarak oksidatik strese karşı hücre savunmasını desteklediği, aynı zamanda yapısında bulunan serbest tiyol grupları ile de direkt antioksidan etki gösterdiği; hidrojen peroksit, hidroksil radikali, hipokloröz asit gibi oksidan moleküllerle etkileşerek radikal toplayıcı etki gösterdiği ileri sürülmektedir. Hem in vitro hem de in vivo çalışmalardan elde edilen kanıtlar, NAC'nin hücre dışı sistini sisteine indirgeyerek veya sülfhidril (-SH) grupları sağlayarak GSH sentezini uyardığı ve glutatyon-S-transferaz aktivitesini artırarak hücre içi GSH'1 yenileyebildiğini göstermektedir (Issels ve ark., 1988). Son yirmi yılda, sayısız in vitro ve in vivo çalışma, NAC'ın kanserojenez, tümörijenez ve mutajenezin yanı sıra tümör büyümesi ve metastazı inhibisyonu dahil olmak üzere faydalı tıbbi özelliklere sahip olduğunu göstermiştir (Kumamato ve ark., 2001).

Kemoterapatik ajanlarla birlikte antioksidan uygulamasının etkisi halen tam olarak bilinmemektedir. Çalışmada kanser tedavisinde kullanılan paklitaksel ile birlikte antioktioksidan molekül olan NAsetilsisteinin MCF7 hücreleri üzerine stotoksik etkisi araştırıldı.

\section{Materyal Ve Yöntem}

Çalışmada MCF-7 meme kanseri hücre hattında paklitaksel sitotoksik etkisi üzerine N-asetil sisteinin antioksidan rolünün gösterilmesi amaçlanmıştır. MCF-7 hücreleri, Haziran 1970 tarihinde, 64 yaşında evre IV invaziv duktal karsinomalı bir kadın olgunun plevral efüzyonundan elde edilmiştir (Soule ve ark., 1973). Çalışmada kullanılan MCF-7 (insan meme adenokarsinoma) hücre hattı Ankara Şap Enstitüsü'nden temin edildi.

MCF-7 hücre hatt1, $37 \mathrm{C}^{\circ} \mathrm{de}, \% 5 \mathrm{CO}_{2}{ }^{\mathrm{e}} \mathrm{li}$, nemli ortamda , \%10 FBS, 2mM L-glutamin, 0,02M non esansiyal aminoasit, $1 \mathrm{mM}$ sodyum piruvat $16 \mathrm{mg} / \mathrm{dL}$ gentamisin içeren DMEM F12 besiyerinde çoğaltıldı. Hücre kültür işlemleri steril laminar hava akımlı çalışma kabininde gerçekleştirildi. Kültür flasklarının \%80-90 kaplandığında, $3 \mathrm{ml}$ Tripsin/EDTA (\% 0.05) ile 3 dakika muamele edilerek, hücrelerin flask zemininden ayrılması sağlandı. Hücreler zeminden kalkınca, besiyeri ile nötralize edilip, 15 ml'lik steril santrifüj tüplerine aktarıldı. Santrifüjlenen hücrelerin, işlem sonrasında süpernatantı atılarak dibe çöken hücre pelleti $10 \mathrm{ml}$ besiyeri ile seyreltildi.

Hücrelerin yeterince çoğalıp çoğalmadığının ve hücre canlılığının değerlendirilmesi için, hücreler tripan mavisi ile boyanarak sayım yapıdı. Pipetajla homojenize edilen hücrelerin süspansiyonundan $100 \mu 1$ alındı ve thoma lamında sayım gerçekleşti.

Çalışmada 9x105/ ml hücre sayıldı. Hücrelerin 24 saatte IC50 sayısını belirlemek amacıyla 1/2, 1/4, 1/8, 1/16 oranlarında sulandırılan hücrelerde WST-1 testi ile canlılık analizi yapıldı. Sitotoksik etki ve metabolik aktivitenin belirlenmesi için yapılan WST-1 testi canlı hücrelerden tetrazolium tuzlarının ayrıştırılmasına dayanan kolorimetrik bir testtir. WST-1 reaktifinde bulunan tetrazolyum tuzu, öncelikle hücre yüzeyinde oluşan karmaşık bir hücresel mekanizma ile çözünür bir formazana bölünür. $\mathrm{Bu}$ biyolojik indirgeme, canlı hücrelerde büyük oranda NAD(P)H'nin glikolitik üretimine bağlıdır. Dolayısıyla formazan boyası miktarı kültürdeki metabolik olarak aktif hücrelerin sayısı ile doğrudan ilişkilidir.

Bu amaçla 96 well plaklara $200 \mu$ l hücre süspansiyonu ilave edildi, 24 saat inkübe edildi. Bu sürenin sonunda ölü hücreler PBS ile 2 kez yıkanarak uzaklaştırıldı, 100 $\mu 1 \% 10$ WST-1 ilave edildi, 3 saat \%5 $\mathrm{CO}_{2}$ ortamında inkübe edildikten sonra 450nm'de absorbanslar okundu. Sonuçlar GraphPad Prism 5 programında değerlendirildi, 24 saatlik MCF-7 hücrelerin IC50 sayısı 3500 olarak hesaplandı. 


\subsection{C50 Dozlarının Belirlenmesi}

Paklitakselin sitotoksik analizlerini yapmak amacıyla 96'llk plaklara her bir kuyucuğa 5000 hücre olacak şekilde $200 \mu 1$ hücre süspansiyonu ilave edildi. Hücreler 24 saat $\% 5 \mathrm{CO}_{2}$ ortamında inkübe edildi. Seri dilusyonlar $(0.5,1,2.5,5,7.5,10,15,20 \mu \mathrm{M})$ halinde hazırlanan farklı konsantrasyonlardaki paklitaksel ihtiva eden medyum hücrelerin üzerine ilave edildi. 24,48 ve 72 saat inkübasyondan sonra WST-1 ile hücre proliferasyon testi yapıldı ve paklitaksel' in IC50 dozu 72.saatte $6 \mu \mathrm{M}$ olarak bulundu.

$\mathrm{N}$-Asetil sistein hücre proliferasyonu üzerine etkisini belirlemek amaciyla hücre mediumunda hazırlanan 100mM stok NAC çözeltisinden 1; 5; 10; 25; 50, 75 mM hazırland1, 24, 48 ve 72 saat inkubasyondan sonra WST-1 ile canlılık testi yapıldı. NAC'1n 72.saat IC50 dozu 7.5mM olarak bulundu.

Sitotoksite düzeyleri aşağıdaki formül ile hesaplandı.

1-(test kuyucuğunun adsorbansı / kontrol kuyucuğunun adsorbansı) x 100

\subsection{N-Asetil Sistein ve Paklitaksel Kombinasyonlart}

Çalışmada MCF-7 meme kanseri hücre hatlarında IC50 dozları dikkate alınarak belirlenen paklitaksel ve $\mathrm{N}$-asetil sistein'in farklı dozlarının tek başına ve kombine uygulanmasındaki olası sinerjistik sitotoksik etkileri araştırıldı.

Çalışmanın başında 96 kuyucuklu hücre kültür plaklarına, toplam $100 \mu$ l volüm içinde 5.000 hücre olacak şekilde ve her bir konsantrasyon için üçlü kontrollü hücre ekimleri yapıldı. Paklitakselin deneyimizde çalışılacak konsantrasyonları 7,5 $\mu \mathrm{M}$ ve $10 \mu \mathrm{M}$ 'dır. N-Asetil Sistein için ise oluşturulan konsantrasyonları $10 \mathrm{mM}, 25 \mathrm{mM}, 50 \mathrm{mM}, 75 \mathrm{mM}$ olarak saptanmıştır. Hücre ekim işleminden sonra 24 saat boyunca inkübatörde bekletilen hücre kültür plaklarına planlanan konsantrasyonlardaki paklitaksel ve $\mathrm{N}$-asetil sistein toplam $100 \mu \mathrm{l}$ volüm içinde olacak şekilde, tek başlarına veya kombine edilecekleri dozlarında 24-48-72 saatlik sitotoksisite analizleri için ekimleri yapıldı ve her bir deney 3 kez tekrarlandı.

\subsection{Kristal Viyole ile Koloni Oluşturma Yeteneklerinin Belirlenmesi}

Klonojenik test hücrelerin üreme ve koloni oluşturma kapasitelerinin araştırılmasında kullanılan bir sitotoksisite testidir. Bu nedenle MCF7 meme kanser hücre hattının paklitaksel ve n-asetil sisteine duyarlılıklarını belirlemede bu yöntemden yararlanıldı. Bu amaçla MCF7 meme kanser hücreleri, 24 kuyulu plakların her kuyucuğunda $1,25 \times 10^{5}$ hücre olacak şekilde ekildi. Hücrelerin yapışmaları için plateler $37 \mathrm{Cde} \% 5 \mathrm{CO} 2$ ve $\% 95$ nem içeren ortamda 24 saat inkübe edildi. Bu sürenin sonunda mikroskopta hücrelerin tutundukları kontrol edilerek, hücreler steril PBS ile yıkand1. P7,5/NAC10, P7,5/NAC25, P7,5/NAC50, P7,5/NAC75, P710/NAC10, P10/NAC25, P10/NAC50, P10/NAC75 konsantrasyonlarda paklitaksel ve N-Asetilsistein hücrelerin üzerine uygulandı ve 72 saat inkübe edildi. İnkubasyonun ardından besiyeri uzaklaştırıldı, PBS ile yıkandı. Hücreler \%10 formaldehit ile oda sıcaklığında 15 dak fikse edildi.

Metanol içinde \%0.5 g olacak şekilde hazırlanan kristal viyole boyasının stok solüsyonundan 1/10 oranında distile su ile dilüe edilerek çalışma solüsyonu hazırlandı. Bu solüsyondan fikse edilen hücrelerin üzerine $250 \mu \mathrm{l}$ eklendi ve $15 \mathrm{dk}$ bekletildi. Inkubasyonun ardından hücreler boyayı uzaklaştırmak için 3 kez distile su ile birer dakikalık periyotlarla yıkandı. Ardından plakalar kapakları açık vaziyette kurumaya bırakıldı. Işık mikroskobu altında değerlendirme yapılarak, sonuçlar fotoğraflandı.

\section{Bulgular}

Meme kanser hücreleri üzerine uygulanan NAC ve paklitakselin sitotoksite sonuçları Tablo 1, 2 ve 3'de gösterilmiştir.Fa rklı doz ve sürelerde NAC uygulanan MCF7 hücre hattında hücre çoğalması 24 saat inkubasyon süresinde, $5 \mathrm{mM}$ dozdan itibaren doz artışına paralel olarak kontrollere göre önemli düzeyde artı̧̧ gösterdi $(\mathrm{p}<0,005)$. 48 ve 72 saatlik inkubasyon sürelerinde $1 \mathrm{mM}, 5 \mathrm{mM}$ ve $10 \mathrm{mM}$ NAC uygulanan hücrelerin çoğalmasında kontrollere göre bir farklılık gözlenmedi ( $>>0,05), 25 \mathrm{mM}$ uygulamada hücre sayısının azaldığı, 50 ve $75 \mathrm{mM}$ da hücrelerin çoğalmasında artış olduğu görüldü ( $<<0,001)$ (Tablo 1).

Paklitakselin 0,5-20 $\mu \mathrm{M}$ arasındaki farklı dozları uygulanan MCF7 hücre hattında 24 saat ve 72 saat inkubasyon sürelerinde bütün uygulamalarda kontrol grubuna göre hücre canlılığında önemli bir azalma görüldü $(\mathrm{p}<0,05)$. 48 saat inkubasyon süresinde hücre canlılığındaki azalma $5 \mu \mathrm{M}$ doz uygulamasından sonra hücre proliferasyonu anlamlı bir şekilde azaldı ( $>>0,05)$. Paklitakselin MCF7 hücreleri üzerine sitotoksik etkisi doz ve zamana bağlı olarak arttığı saptandı (Tablo2).

Paklitaksel ve NAC'ın MCF7 hücreleri üzerine yukarıda belirtilen dozlarda uygulamaların sitotoksite sonuçlarının CompuSYN 1.0 (CombeSyn Inc., Paramus, NJ, USA) programı kullanılarak hesaplanan IC50 dozlarına göre paklitaksel-NAC kombinasyonları belirlendi. 24 saat inkubasyon süresinde artan konsantrasyonlarda P/NAC uygulamasının hücre proliferasyonunu istatistik olarak anlamlı bir şekilde $\operatorname{artırdığ~}_{1}$ görüldü $(\mathrm{p}<0,05)$. Kombinasyonların uygulandı̆̆ 
tutulduğunda kontrollere göre hücrelerin daha fazla çoğaldı̆ğ $(\mathrm{p}<0,05)$, ancak bu artışı 24 saat inkubasyon süresine göre daha yavaş olduğu; P7,5/NAC25, P10/NAC10, P10/NAC25 dozlarındaki değişimlerin ise kontrol grubuna göre önemli olmadığ bulundu ( $>0,05)$. Paklitaksel ve N-Asetilsistein kombinasyonlarının uygulandığ 1 MCF7 hücreler, 72 saat inkube edildiğinde P7,5/NAC25 uygulanan hücrelerin proliferasyonu ile kontroller arasında bir fark bulunmazken ( $>00,05)$, diğer doz uygulamalarında önemli değişimler tespit edildi $(\mathrm{p}<0,05)$. P7,5/NAC10; P10/NAC10; P10/NAC25 uygulama gruplarında hücre çoğalması kontrollere göre düşerken diğer uygulamalarda yüksek olduğu görüldü $(\mathrm{p}<0,05)$.

Tablo 1. NAC'1n doz ve zamana bağlı olarak MCF7 hücre çoğalması üzerine etkisinin istatistiki değerlendirilmesi

\begin{tabular}{|c|c|c|c|c|c|c|}
\hline \multirow{2}{*}{$\begin{array}{c}\text { N-Asetilsistein } \\
\text { (mM) }\end{array}$} & \multicolumn{2}{|c|}{$\mathbf{2 4}$ h WST-1 } & \multicolumn{2}{|c|}{$\mathbf{4 8}$ h WST-1 } & \multicolumn{2}{|c|}{$\mathbf{7 2}$ h WST-1 } \\
\cline { 2 - 7 } & $\begin{array}{c}\text { \% hücre } \\
\text { çoğalması }\end{array}$ & $\mathrm{p}$ & $\begin{array}{c}\text { \%hücre } \\
\text { çoğalmas }\end{array}$ & $\mathrm{p}$ & $\begin{array}{c}\text { \% hücre } \\
\text { çoğalmas1 }\end{array}$ & $\mathrm{p}$ \\
\hline Kontrol & 100 & & 100 & & 100 & \\
\hline $\mathbf{1}$ & 99,4 & 1 & 100,8 & 1 & 104,3 & 0,123 \\
\hline $\mathbf{5}$ & 109,9 & 0,006 & 99,4 & 1 & 106,4 & 0,030 \\
\hline $\mathbf{1 0}$ & 129,9 & 0,000 & 97,2 & 0,432 & 67,6 & 0,000 \\
\hline $\mathbf{2 5}$ & 183,5 & 0,000 & 83,9 & 0,001 & 85,4 & 0,001 \\
\hline $\mathbf{5 0}$ & 193,8 & 0,000 & 126,1 & 0,000 & 118,9 & 0,000 \\
\hline $\mathbf{7 5}$ & 217,9 & 0,000 & 131,9 & 0,000 & 121,4 & 0,000 \\
\hline
\end{tabular}

Tablo 2. Paklitakselin doz ve zamana bağlı olarak MCF7 hücre çoğalması üzerine etkisinin istatistiki değerlendirilmesi

\begin{tabular}{|c|c|c|c|c|c|c|}
\hline \multirow{2}{*}{$\begin{array}{c}\text { Paklitaksel } \\
\qquad(\mu \mathrm{Mol})\end{array}$} & \multicolumn{2}{|c|}{24 h WST-1 } & \multicolumn{2}{|c|}{48 h WST-1 } & \multicolumn{2}{|c|}{72 h WST-1 } \\
\hline & $\begin{array}{l}\text { \% hücre } \\
\text { çoğalmas1 }\end{array}$ & $\mathrm{p}$ & $\begin{array}{l}\text { \% hücre } \\
\text { çoğalması }\end{array}$ & $\mathrm{p}$ & $\begin{array}{l}\text { \% hücre } \\
\text { çoğalması }\end{array}$ & $\mathrm{p}$ \\
\hline Kontrol & 100 & & 100 & & 100 & \\
\hline 0,5 & 87,2 & 0,003 & 91,9 & 0,021 & 87,9 & 0,004 \\
\hline 1 & 87,7 & 0,004 & 91,7 & 0,190 & 85,7 & 0,020 \\
\hline 2,5 & 87,2 & 0,003 & 91,4 & 0,160 & 91,4 & 0,016 \\
\hline 5 & 83,1 & 0,001 & 88,8 & 0,006 & 89,3 & 0,007 \\
\hline 7,5 & 81,7 & 0,001 & 86,7 & 0,003 & 87,6 & 0,004 \\
\hline 10 & 79,5 & 0,001 & 79,5 & 0,001 & 81,5 & 0,001 \\
\hline 15 & 66,1 & 0,000 & 65,3 & 0,000 & 53,5 & 0,000 \\
\hline 20 & 53,4 & 0,000 & 46,2 & 0,000 & 30,2 & 0,000 \\
\hline
\end{tabular}


Tablo 3. Paklitaksel ve NAC kombinasyonlarının doz ve zamana bağlı olarak MCF7 hücre çoğalması üzerine etkisinin istatistiki değerlendirilmesi (P:Paklitaksel, NAC:N-Asetilsistein)

\begin{tabular}{|c|c|c|c|c|c|c|}
\hline \multirow[t]{2}{*}{ Kombinasyonlar } & \multicolumn{2}{|c|}{24 h WST-1 } & \multicolumn{2}{|c|}{48 h WST-1 } & \multicolumn{2}{|c|}{72 h WST-1 } \\
\hline & $\begin{array}{c}\text { \%hücre } \\
\text { çoğalmas1 }\end{array}$ & $\mathrm{p}$ & $\begin{array}{c}\text { \%hücre } \\
\text { çoğalmas1 }\end{array}$ & $\mathrm{p}$ & $\begin{array}{l}\text { \%hücre } \\
\text { çoğalması }\end{array}$ & $\mathrm{p}$ \\
\hline Kontrol & 100 & & 100 & & 100 & \\
\hline P7,5/NAC10 & 87,1 & 0,010 & 70,6 & 0,000 & 38,8 & 0,000 \\
\hline P7,5/NAC25 & 127,7 & 0,000 & 112,3 & 0,120 & 103,6 & 0,707 \\
\hline P7,5/NAC50 & 153,8 & 0,000 & 157,9 & 0,000 & 120,6 & 0,002 \\
\hline P7,5/NAC75 & 186,4 & 0,000 & 161,1 & 0,000 & 116,9 & 0,003 \\
\hline P10/NAC10 & 97,3 & 0,953 & 90,3 & 0,300 & 87,2 & 0,010 \\
\hline P10/NAC25 & 117,4 & 0,003 & 110,1 & 0,250 & 88,5 & 0,015 \\
\hline P10/NAC50 & 168,1 & 0,000 & 149,6 & 0,000 & 121,1 & 0,001 \\
\hline P10/NAC75 & 211,0 & 0,000 & 179,7 & 0,000 & 127,6 & 0,000 \\
\hline
\end{tabular}

3.1.Paklitaksel-NAC Kombinasyon uygulamalarının MCF7 hücreleri üzerine Kristal Viyole ile Koloni Oluşturma Yetenekleri

NAC ve pakitakselin MCF7 hücre hattına 72 saat inkubasyon süresinde koloni oluşturabilme yeteneği üzerine etkileri kristal viyolet boyamasının ardından görüntülenerek Şekil 1'de verilmiştir. Paklitakselin yüksek dozlarının doz artışına paralel olarak hücrelerin koloni oluşturma yeteneğini azalttığı; NAC'ın ise $10 \mathrm{mM}$ NAC uygulaması koloni oluşturma sonuçları kontrole yakınken, 25, 50 ve $75 \mathrm{mM}$ NAC ilave edilen uygulamalarda daha az olduğu görüldü. Paklitaksel ve NAC kombinasyon uygulanan MCF7 hücrelerinde ise kontrollere göre belirgin bir biçimde koloni oluşturma yeteneklerinin azaldığg, paklitakselin sitotksik etkisini ise ilave edilen NAC'ın azalttığı, hücre kolonisi oranının artırdığı kristal viyole sonuçlarında belirgin bir şekilde görülmektedir.

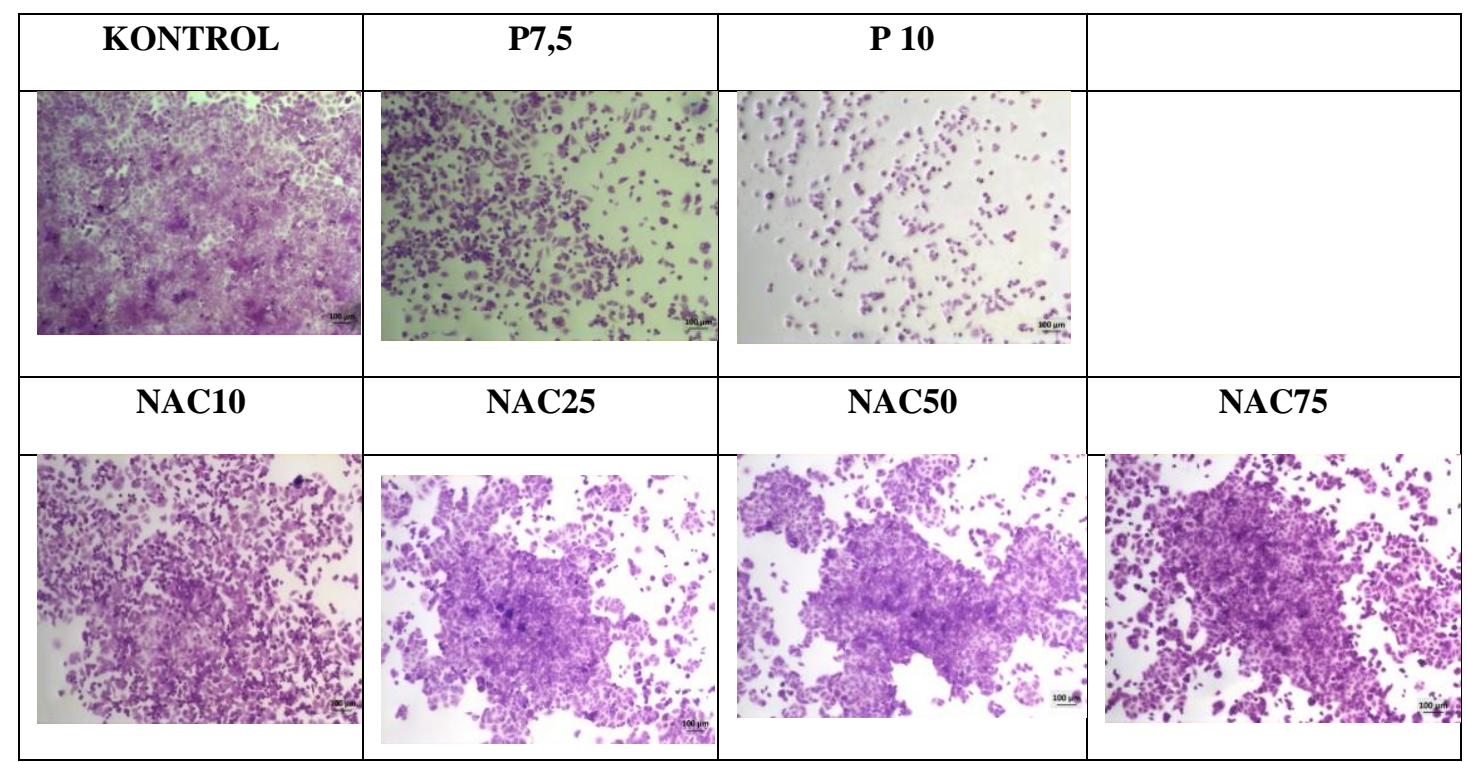




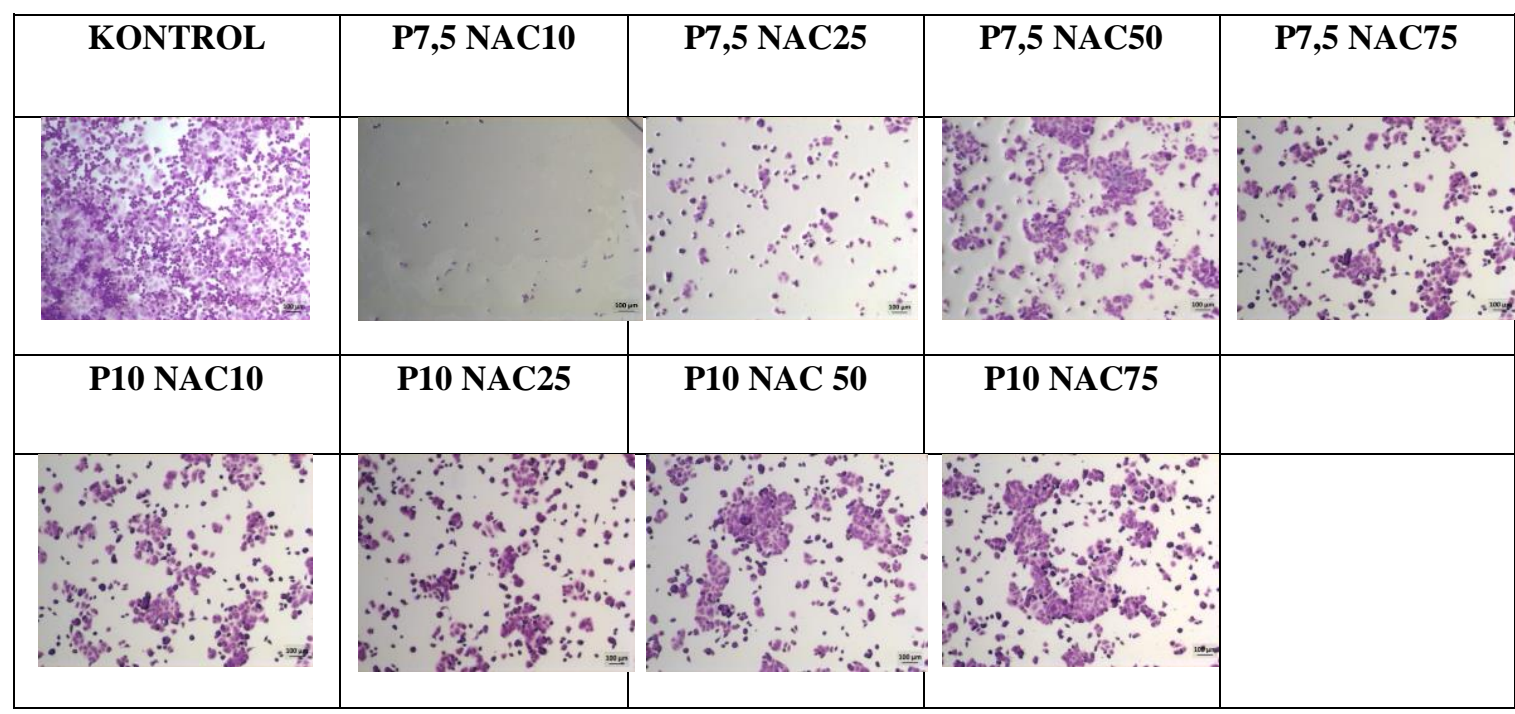

Şekil 1. NAC ve paklitakselin MCF7 meme kanser hücre hattında 72 saat inkubasyon süresinde hücrelerin koloni oluşturabilme yeteneği üzerine etkisi

\section{Tartışma}

Konvansiyonel kanser tedavileri sırasında eşzamanlı antioksidan kullanımı konusunda yoğun bir tartışma vardır. Oksidatif stresin, antineoplastik ajanların kanser hücreleri üzerinde optimal sitotoksisiteleri için gerekli olan hücresel işlemlere müdahale ettiği ve hafif oksidatif stres seviyelerinin, antikanser ilaçların sitotoksisitesini azalttığı ileri sürülmüştür. $\mathrm{Bu}$ nedenle, antikanser ilaçları uygulandığında meydana gelen ROS oluşumunun tedavinin etkinliğini azalttığı iddia edilmiştir. Buna karşılık, antineoplastik ajanların neden olduğu yan etkilerin bir kısmı bazı antioksidanlar tarafindan önlendiği görüldüğünden kemoterapi sırasında bu antioksidan takviyesinin yan etkileri azaltabileceği ve tedaviye yanıtı artırabileceği görüşü de ileri sürülmektedir (Ozben, 2007). Bu bilgiler ışığında son zamanlarda artan sayıda hasta, antioksidanlarla tamamlayıcı tedavilere yönelirken; birçok onkolog antioksidanların aleyhine dönmüştür; hastalarını konvansiyonel kanser tedavisi sırasında antioksidan kullanmamaları konusunda uyarmaktadır. Bu argüman radyasyon tedavisi ve bazı kemoterapi ilaçlarının kanser hücrelerini öldüren reaktif oksijen türleri (ROS) ürettiği gerçeğine dayanmaktadır. Antioksidanlar kemoterapiye müdahale edebilir ve kanser hücrelerinin ROS tarafindan öldürülmesini önleyebilir, bu nedenle geleneksel kanser tedavisi sırasında eşzamanlı antioksidan kullanımından kaçınılması gerektiği öne sürülmektedir (Akbas ve ark., 2006). Bu tartışma bilimsel alanlarda halen devam etmektedir. Bu bağlamda MCF7 meme kanser hücre hattında, N-Asetilsisteinin kemoterapotik ajan olan paklitakselin ile kombinasyonunun hücreler üzerinde sitotoksik etkisi araştırılmıştır.

Çok sayıda in vitro çalışma, çok çeşitli antikanser ajanların, kanserde önemli terapötik girişimsel yaklaşımlardan biri olan ROS üreterek malign hücrelerde apoptozu indüklediğini göstermiştir (Papet ve ark., 2011, Özfiliz, 2013). Kemoterapotiklerle birlikte antioksidanların kemoprotektif uygulamalarının ROS'u süpürerek ROS'un indüklediği apoptoz tarafından kanser hücrelerinin öldürülmesini önleyebileceği iddia edilmektedir (Akbas ve ark., 2006; Ozben, 2007). Ancak durum belirtilenden daha karmaşıktır. Her ne kadar birçok kemoterapi ilacı serbest radikal oluşumunu indüklese de, antikanser etkileri sadece serbest radikallere bağlı değildir. Antioksidan, serbest radikallerin neden olduğu yan etkileri önlerken kemoterapinin etkilerini artırabilir (Ozben, 2007) .

N-Asetilsistein, düşük molekül ağırlıklı tiyol içeren bir antioksidandır, serbest radikal temizleme özelliği, tiyol grubunun nükleofilikliği ve redoks etkileşimlerine bağlanmıştır. Ek olarak, NAC genellikle de novo GSH sentezinin sınırlayıcı öncüsü olan bir sistein kaynağıdır. Glutatyon, canlı hücrelerde bulunan en bol miktarda protein olmayan tiyol olduğu ve seviyeleri hücre içi antioksidan durumunun bir göstergesi olarak kullanıldığı için önemli bir antioksidandır (Duval ve ark.,2013). Hücrenin en önemi antioksidanlarından olan glutatyon (GSH), vücut homeostazının korunmasında ve hücrelerin oksidanlara, toksik maddelere, DNA'ya zarar veren ajanlara ve eksojen veya endojen kaynaklı kanserojenlere karşı korunmasında merkezi bir fizyolojik rol oynar. Ne yazık ki, büyük GSH molekülü, hücrelere verimli bir şekilde taşınmamaktadır. Ayrıca, bu tripeptidin ( $\gamma$-glutamil-L-sisteinil glisin) hücre

197 | P a g e

www.iiste.org 
içi sentezindeki hızı sınırlayan amino asit olan L-sistein insanlar için toksiktir. N-asetil-L-sistein (NAC), L-sistein elde etmek üzere hücrelerde kolayca deasetile edilir, böylece hücre içi GSH sentezini arttırır. GSH öncüsü olarak bu aktivitenin yanı sıra, NAC, ksenobiyotiklerin toksikokinetiğini etkileyen nükleofilik ve antioksidan özelliklerinden dolayı hücre dışı ortamdaki koruyucu etkilerden sorumludur. 1960'larda mukolitik bir ajan olarak tanıtılan N-Asetilsistein, akut bronşit, kronik bronşit ve akut solunum güçlüğü sendromu ve influenza gibi solunum yolu hastalıklarının tedavisinde ve profilaksisinde çok kapsamlı klinik uygulamalarda kullanılmıştır. Ayrıca NAC, parasetamol doz aşımının neden olduğu akut zehirlenmelerde ve doksorubisin, siklofosfamid ve ifosfamid gibi antikanser ilaçların toksisitesine karşı bir panzehir olarak da kullanılmıştır (De Flora ve ark.,2001). NAC'nin hücre zarlarını lipid peroksidasyonuna ve protein oksidasyonuna karşı koruyabileceği ve hücresel organellerin bütünlüğünün korunmasına yardımcı olabileceği önerilmektedir. Bununla birlikte, NAC'nin apoptoz gibi temel hücresel süreçleri etkileyip etkilemediği ve nasıl etkilediği henüz belirlenmemiştir (Mansour ve ark.2008, Neal ve ark.,2003, Spapen, 2004).

$\mathrm{N}$-Asetil sistein, E vitamini ile birlikte kolon karsinomu hücrelerinde Bax proteininin indüksiyonunu

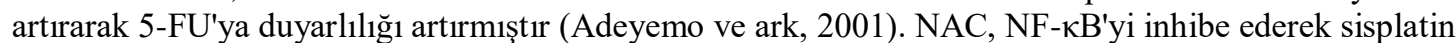
ve etoposidin prostat kanseri hücreleri üzerindeki kemoterapötik etkisini arttırdığı görülmüştür (Tozawa ve ark., 2002). NAC'in kolorektal (Nargi ve ark.,1999), mesane (Kawakami ve ark, 2001), prostat (Lee ve ark.2011) ve akciğer (Hann ve ark.,2013) karsinoma hücresi dahil olmak üzere invitro kanser hücrelerinin büyümesini, çoğalmasını inhibe ettiği bildirilmiştir. NAC'ın, kemoterapötik ilaçların (Bach ve ark.,2011; Brum ve ark.2013), interferon a (Kretzmann ve ark.,2012), bakır (Zheng ve ark., 2010) ve epigallocatechin-3-gallatın (Lambert ve ark. 2008) sitotoksik etkileriyle etkileşime girdiği ve kanser hücreleri üzerindeki etkilerini arttırdığı da gösterilmiştir. Buna karşılık, birkaç çelişkili rapor da mevcuttur. Sceneay ve ark. (2013), NAC in vitro meme kanseri hücrelerinin proliferasyonunu inhibe etmediğini, in vivo olarak tümör büyümesini engellemediğini, hatta daha da arttırdığını rapor etti. Amini ve ark., (2014) ise MKN45, KATO-III, HT29-5F12, HT29-5M21 and LS174T gastrointestinal kanser hücresi hatlarında 10, 25, 50, 75 mM NAC 72 saat uygulamasının doz artışıyla birlikte sitotoksik etki gösterdiğini saptamışlardır, bu etkiler bleomycin kombinasyonuyla birlikte artmıştır.

Paklitaksel, Pasifik porsuk ağacının kabuğundan izole edilen doğal bir alkaloiddir, yumurtalık, meme ve küçük hücreli dışı akciğer kanserleri de dahil olmak üzere çeşitli kanserlerin tedavisinde kullanılmaktadır. Paklitaksel, mitotik G2 / M fazını durduran ve apoptoz ile sonuçlanan tübülin polimerizasyonuyla ve mikrotüpleri stabilize ederek antikanser aktivitesini uyaran antimikrotubül bir ajanıdır (Saunders ve ark., 1997). Paklitakselin ayrıca kanser hücrelerinde erken reaktif oksijen türü (ROS) ve hidrojen peroksit üretimine neden olarak hem in vitro hem de in vivo olarak paklitaksel kaynaklı kanser hücresi ölümüne katıldığı bulunmuştur (Ramanathan ve ark., 2005).

Kanser tedavisi gören birçok hasta, kemoterapinin toksisitesini düşürmek amaciyla diyet takviyeleri, özellikle antioksidanlar kullanmaktadır. Antioksidanların sitotoksik tedavinin etkinliği artıran araştırma sonuçlar1 olduğu gibi (Hans Konrad ve Jürgen, 2003; Ladas ve Kelly, 2010; Muralikrishnan ve ark., 2010); antioksidanların konvansiyonel sitotoksik tedavilerin etkilerini azaltabileceğini gösteren kanıtlar da vardır. Kucuksayan ve ark. (2013), insan cancer testis hücrelerinde (NTERA-2, NT2), NAC'ın bleomisinle indüklenen apoptozun mitokondriyal ve ölüm reseptör yolaklarını azalttığını göstermiştir. NAC'nin bleomisin kaynaklı apoptoz üzerindeki bu antiapoptotik davranışını büyük olasılıkla bleomisin tarafından üretilen ROS'u temizleyen güçlü antioksidan özelliğinden kaynaklandığını düşünmüşlerdir. Apoptoz üzerinde olumsuz etkisi olan NAC gibi antioksidanların dikkatli tüketilmesi veya konvansiyonel kanser tedavisi sırasında kemoterapötik ajanlarla eşzamanlı kullanımından kaçınılması gerektiği sonucuna varmışlardır (Kucuksayan ve ark, 2013).

Paklitaksel ve FUdR ile muamele edilmiş meme karsinomu hücre hatlarında (MCF-7 veya MDA MB435S), epigallocatechin gallat, fenetil izotiyosiyanat ve tert-butilhidrokino gibi antioksidanların etkilerini inceleyen bir çalışmada, antioksidanlarla eşzamanlı tedavinin kemoterapötik ajanların etkinliğini azalttığı ve antioksidanların sağkalımı artırdığı, antioksidan cevabı düzenleyen gen ekspresyonunu indüklediği bulunmuştur (De Larco ve ark. 2010). İnsan adenokarsinom alveoler epitel hücrelerinin ( A549), $5.0 \mathrm{mM}$ NAC ve $1.0 \mu \mathrm{M}$ paklitaksel ile 24 saatlik bir inkübasyon süresi sonunda NAC, Paklitakselin hücreler üzerindeki hücre içi ROS artış1, apoptotik etkisini ve hücre üzerindeki doz ve zamana bağlı sitotoksik etkisini azalttığı rapor edilmiştir (Lyle ve ark., 2011). Resveratrolun, bazı insan meme kanseri hücre hatlarında paklitakselin antikanser etkilerinin hem in vitro hem de in vivo olarak etkinliğini azalttığı. bu etkiyi paklitakselin neden olduğu G2 / M hücre döngüsünün durmasının engellenmesinden ve paklitaksel kaynaklı ROS birikiminin baskılanması; ardından anti-apoptotik Bcl2'nin etkisizleştirilmesi sonucu ortaya çıktığı ileri sürülmüştür. (Fukui ve ark., 2010) 
Ayrıca, normal hücreleri sitotoksik uyarıcılara karşı koruyan NAC'ın anti-apoptotik etkilerini ortaya koyan kanıtlara rağmen, NAC'nin pro-apoptotik bir rolü için tartışılan raporlar da vardır. Tsai ve ark. (1996), NAC'nin aortik düz kas hücrelerinde apoptozu indüklediğini ancak endotel hücrelerinde olmadığını bildirmiştir. Benzer olarak Havre ve ark. (2002), NAC'ın seçici olarak p53 aracılı apoptozu, onkojenik olarak transforme edilmiş fibroblastlarda seçici bir şekilde indüklediğini, ancak normal hücrelerde indülemediğini belirtmiştir. Cho ve ark. (2014), NAC'ın meme kanseri hücrelerinde ROS üretimini ve Akt fosforilasyonunu azalttığını ve apoptotik hücre ölümüne neden olduğunu bulmuşlardır. MCF7 hücrelerinde antikanser olarak etkili olduğu bilinen Triphala (TPL)'nın sitotoksik etkisi NAC tarafından önlenmiş, hücre proliferasyonunu artırmıştır (Sandhya ve Mishra, 2006).

Yapılan araştırmada kematerapotik bir ajan olarak meme kanseri tedavisinde kullanılan Paklitakselin MCF7 meme kanser hücreleri üzerine sitotoksik etkisinin doz ve zamana bağlı arttığ 1 , 72. saatte hücrelerin $\% 50$ oranında ölümüne yol açtığ1 gösterilmiştir. NAC'ın ise bu hücrelerde sitotksik etki yapmadığ1 hücre proliferasyonuna destek olduğu görülmüştür. 24.saat'den sonra hücre çoğalması azalmış, ancak doz artışı ile birlikte hücre çoğalması uyarılmıştır. Bu sonuçlar NAC MCF7 hücreleri üzerine sitoksik etki etmediğini tersine proliferatif etki yaptığını göstermektedir. NAC'ın meme kanser hücreleri üzerindeki proliferetif etkisi paklitaksel ile birlikte kombine uygulandığında da devam etmiş, paklitakselin sitotoksik etkisi zayıflamıştır. Kombinasyonların uygulandığı MCF7 hücrelerinin koloni oluşturabilme yetenekleri de sitotoksite sonuçlarını desteklemektedir. NAC ilave edilen meme kanser hücrelerinde koloni formları gözle görülür bir şekilde artmıştır. Paklitakselin, kanser hücrelerinde erken reaktif oksijen türü (ROS) ve hidrojen peroksit oluşumunu uyararak etki ettiği bilindiğinden güçlü bir antioksidan olan NAC'ın ROS süpürücüsü rolünden kaynaklandığı düşünülebilir. Araştırmada, antioksidan ve kemoterapik ilaçlar birlikte verildiğinde kemoterapinin etkisinin azaldığını iddia eden çalışma sonuçlarına benzer sonuçlar elde edildi, ancak bu etki yukarıda ayrıntıları verilen araştırmalarda sunulduğu gibi hücre tipine ve içeriğine göre değişebilir.

\section{Kaynaklar}

Adeyemo, D. et al.(2001). Antioxidants enhance the susceptibility of colon carcinoma cells to 5fluorouracil by augmenting the induction of the bax protein, Cancer Lett, 164(1), 77-84.

Akbas, H.S. et al. (2006). 'Concurrent use of antioxidants in cancer therapy: An update', Expert Review of Clinical Immunology, 2(6), pp. 931-939. doi: 10.1586/1744666X.2.6.931.

Amini, A. et al. (2014). 'Bromelain and N-acetylcysteine inhibit proliferation and survival of gastrointestinal cancer cells in vitro: significance of combination therapy', Journal of Experimental \& Clinical Cancer Research, 33, pp. 1-15. doi: 10.1186/s13046-014-0092-7.

Bach, S.P. et al. (2001). The antioxidant n-acetylcysteine increases 5-fluorouracil activity against colorectal cancer xenografts in nude mice, J Gastrointest Surg, 5:91-97.

Brum, G. et al. (2013). N-acetylcysteine potentiates doxorubicin-induced ATM and p53 activation in ovarian cancer cells, Int J Oncol, 42:211-218.

Cadenas, E. \& Davies, K.J.A.(2000). Mitochondrial free radical generation, oxidative stress, and aging, Free Rad. Biol. Med. 29, 222-230.

Cho, S.G. et al. (2014). Butein suppresses breast cancer growth by reducing a production of intracellular reactive oxygen species, J Exp Clin Cancer Res, 33:51.

De Flora, S. et al. (2001). Mechanisms of N-acetylcysteine in the prevention of DNA damage and cancer, with special reference to smokingrelated end-points, Carcinogenesis, 22: 999-1013

De Larco, J.E. et.al. (2010). Paradoxical roles for antioxidants in tumor prevention and eradication, Cancer Biol Ther, 9: 362-370.

Duran, L. et al., (2011). Parasetamol Zehirlenmesinde İntravenöz N-Asetil Sistein Kullanımı, JAEM: 145-7. doi:10.5152/jaem.2011.072. 
Duval, D. et al. (2013). Neuroprotective effects of N-acetylcysteine: a review, Brain Res. J., 6, 309-337.

Fukui, M. et al. (2010). Resveratrol at- tenuates the anticancer efficacy of paclitaxel in human breast cancer cells in vitro and in vivo,Eur J Cancer, 46: 1882-1891.

Hann, S.S. et al. ( 2013). Targeting 3-phosphoinositide-dependent protein kinase 1 by N-acetylcysteine through activation of peroxisome proliferators activated receptor alpha in human lung cancer cells, the role of p53 and p65. J Exp Clin Cancer Res, 32:43

Hans Konrad, B. \& Jürgen, F. (2003). Antioxidants in cancer therapy: is there a rationale to recommend antioxidants during cancer therapy? Biofactors, 17: 229-240.

Havre, P.A. et al. (2002). Transformed and tumor-derived human cells exhibit preferential sensitivity to the thiol antioxidants, N-acetyl cysteine and penicillamine, Cancer Res, 62:1443-1449.

Issels, R.D. et al. (1988). Promotion of cystine uptake and its utilization for glutathione biosynthesis induced by cysteamine and N-acetylcysteine, Biochem. Pharm. 37: 881-888.

Kars Demirel, M. et al. (2009). 'Meme kanseri MCF-7 hücre hattında paklitaksel ve vinkristin ' e karşı gelişmiş çoklu ilaç direnci mekanizmalarının mikrodizin analizi ile belirlenmesi', Türk Onkoloji Dergisi, 24(4), pp. 153-158.

Kawakami, S. et al. (2001). Inhibitory effect of N-acetylcysteine on invasion and MMP-9 production of T24 human bladder cancer cells, Anticancer Res, 21:213-219.

Kretzmann, N.A. et al. (2012). N-acetylcysteine improves antitumoural response of Interferon alpha by NF-kB downregulation in liver cancer cells, Comp Hepatol, 11:4

Kucuksayan, E. et al. (2013). N-acetyl-l-cysteine inhibits bleomycin induced apoptosis in malignant testicular germ cell tumors, J Cell Biochem, 114:1685-1694.

Kumamoto, M. et al. (2001). Effects of $\mathrm{pH}$ and metal ions on antioxidative activities of catechins, Biosci. Biotechnol. Biochem, 65.126- 132.

Ladas, E. \& Kelly, K.M. (2010).The antioxidant debate, Explore (NY), 6: 75-85.

Lambert, J.D. et al. (2008). N-Acetylcysteine enhances the lung cancer inhibitory effect of epigallocatechin-3-gallate and forms a new adduct, Free Radic Biol Med, 44:1069-1074.

Lee, Y.J. et al.( 2011). Suppression of human prostate cancer PC-3 cell growth by N-acetylcysteine involves over-expression of Cyr61, Toxicol In Vitro, 25:199-205.

Lyle, P.A. et al.(2011). 'N-acetylcysteine modulates the cytotoxic effects of paclitaxel', Chemotherapy, pp. 298-304. doi: 10.1159/000329510.

Mansour, H.H. et al. (2008). Protective effect of N-acetylcysteine against radiation induced DNA damage and hepatic toxicity in rats, Bioch. Phar. 75: 773-780.

Masella, R, et al. (2005). Novel mechanisms of natural antioxidant compounds in biological systems: involvement of glutathione and glutathione-related enzymes, J. Nutr. Biochem. 16, 577-586.

Mates, J.M. et al. (1999). Antioxidant enzymes and human diseases, Clin. Biochem. 32,595-603.

McCall, M.R. \& Fre, B. (1999). Can antioxidant vitamins materially reduce oxidative damage in humans? Free Rad. Biol. Med. 26, 1034-1053. 
Muralikrishnan, G. et al. (2010). Effect of vitamin C on lipidperoxidation and anti- oxidant status in tamoxifen-treated breast cancer patients, Chemotherapy, 56: 298-302.

Nargi, J.L. et al. (1999). p53-independent inhibition of proliferation and p21(WAF1/Cip1)modulated induction of cell death by the antioxidants $\mathrm{N}$-acetylcysteine and vitamin E, Neoplasia, 1:544-556

Neal, R. et al. (2003). Antioxidant role of N-acetyl cysteine isomers following high dose irradiation, Free Radic Biol Med 34: 689-695. 41.

Ozben, T., (2007). 'Oxidative Stress and Apoptosis: Impact on Cancer Therapy', Journal of pharmaceutical sciences, 96(9), pp. 2181-2196. doi: 10.1002/jps.

Özfiliz, P. ( 2013). "Bag-1 Silencing Enhanced Cisplatin or Paclitaxel Induced Apoptosis in MCF-7 Breast Cancer Cells.”, İstanbul Teknik Üniversitesi, Fen Bilimleri Ens., yüksek lisans tezi

Papet, C. et al.(2011). Two cases of cerebral sinus venous thrombosis following chemotherapy for non-seminomatous germ cell tumor, Case Rep Oncol 4:555-55

Poli, G. et al. (2004). Oxidative stress and cell signalling, Curr. Med. Chem. 11, 1163-1182.

Ramanathan, B. et al. ( 2005). 'Resistance to paclitaxel is proportional to cellular total antioxidant capacity', Cancer Research, 65(18), pp. 8455-8460. doi: 10.1158/0008-5472.CAN-05-1162.

Sandhya, T. \& Mishra, K.P. (2006). 'Cytotoxic response of breast cancer cell lines, MCF7 and T 47 D to triphala and its modification by antioxidants.', Cancer letters, 238(2), pp. 304-13. doi: 10.1016/j.canlet.2005.07.013.

Sceneay, J. et al. ( 2013). The antioxidant N-acetylcysteine prevents HIF-1 stabilization under hypoxia in vitro but does not affect tumorigenesis in multiple breast cancer models in vivo, $P L o S$ One, 8:e66388.

Soule, H.D. et al.(1973). A human cell line from a pleural effusion derived from a breast carcinoma, J Natl Cancer Inst, 51:1409-1413.

Spapen, H. (2004). N-acetylcysteine in clinical sepsis: a difficult marriage, Crit. Care. 8: 229-230

Tozawa, Ke. et al. (2002). N-acetyl-L-cysteine enhances chemotherapeutic effect on prostate cancer cells, Urol. Res. 30(1), 53-58.

Tsai, J.C. et al. (1996). Induction of apoptosis by pyrrolidinedithiocarbamate and N-acetylcysteine in vascular smooth muscle cells, J Biol Chem, 271:3667-3670

Valko, M. et al. ( 2007). 'Free radicals and antioxidants in normal physiological functions and human disease.', The International Journal Of Biochemistry \& Cell Biology, 39, pp. 44-84. doi: 10.1016/j.biocel.2006.07.001.

Valko, M. et al. (2006). Free radicals, metals and antioxidants in oxidative stress-induced cancer, Chemico-Biological Interactions 160, 1-40

Zheng, J. et al. (2010). N-Acetylcysteine interacts with copper to generate hydrogen peroxide and selectively induce cancer cell death, Cancer Lett, 298:186-194 